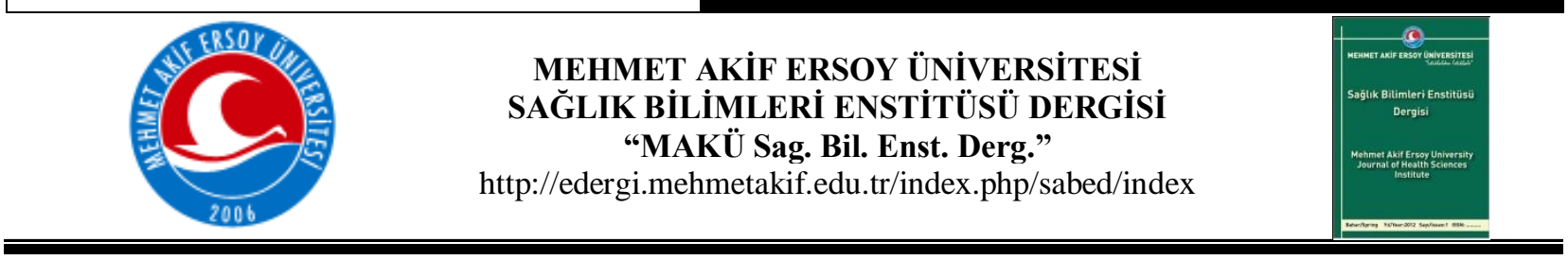

\title{
Mycobacterium avium subspecies paratuberculosis'in makrofajlar içinde hayatta kalma stratejileri
}

\author{
Survival strategies of Mycobacterium avium subspecies paratuberculosis within the \\ macrophages

\section{Ezgi Şababoğlu ${ }^{1}$, Hülya Türütoğlu} \\ ${ }^{1}$ Mehmet Akif Ersoy Üniversitesi, Veteriner Fakültesi, Mikrobiyoloji Anabilim Dalı BURDUR, TÜRKIYY
}

\begin{abstract}
Paratuberculosis (Johne's disease) is a disease of domestic and wild ruminants caused by Mycobacterium avium subspecies paratuberculosis (Map). It is not yet fully understood how the agent, which has a broad host range and has developed various strategies to survive in inappropriate conditions, can survive. In this review; the early host defenses developing in Map infection, the strategies employed by the pathogen to avert these responses and how persistent infection has occured, in macrophages, has been explained.
\end{abstract}

Key words: Host defense, macrophage, Mycobacterium avium subspecies paratuberculosis.

Yazışma Adresi: Arş. Gör. Ezgi ŞABABOĞLU, Mehmet Akif Ersoy Üniversitesi, Veteriner Fakültesi, Mikrobiyoloji Anabilim Dalı, İstiklal Yerleşkesi, 15030-Burdur, Türkiye.

E-posta: ezgisababoglu@mehmetakif.edu.tr

Tel: +902482132067

Kaynak göstermek için: Şababoğlu E, Türütoğlu H. 2017. Mycobacterium avium subspecies paratuberculosis' in makrofajlar içinde hayatta kalma stratejileri MAKÜ Sag. Bil. Enst. Derg. 5(2): 144-154
Öz: : Paratüberküloz (Johne hastalı̆̆), Mycobacterium avium subspecies paratuberculosis (Map) tarafindan oluşturulan evcil ve yabani ruminantların bir hastalığıdır. Geniş bir konakçı dağlımına sahip olan ve uygun olmayan koşullarda hayatta kalmak için çeşitli stratejiler geliştirmiş olan etkenin nasıl canlı kalabildiği henüz tam olarak anlaşılamamıştr. Bu derlemede; Map enfeksiyonunda meydana gelen erken konakçı yanıtı, bu yanitı engellemek için patojenin kullandığı stratejiler ve makrofajlarda nasıl kalıcı enfeksiyonun oluştuğu açıklandı.

Anahtar sözcükler: Konakçı savunması, makrofaj, Mycobacterium avium subspecies paratuberculosis.

Geliș Tarihi: $30.06 .2017 \quad$ Kabul Tarihi: 21.11 .2017 


\section{Giriş}

Paratüberküloz, özellikle sütçü sı̆ğrlar olmak üzere ruminantları ve birçok evcil ile yabani hayvan türünü etkileyen, Mycobacterium avium subspecies paratuberculosis (Map) tarafindan oluşturulan kronik, progresif, infeksiyöz granulomatoz enterit ile karakterize bir hastaliktır (Lamont, 2012; Yardımcı 2006). Karkas değerinde düşmeye ve süt üretiminde azalmaya yol açarak hayvancllıkta büyük ekonomik kayıplara neden olan bu hastalığın önemi günümüzde halen devam etmektedir. Hastalığın sadece Amerika Birleşik Devletleri'nde yılda 250 milyon dolar zarara neden olduğu bildirilmiştir (Ott ve ark., 1999). Hastalı̆ğn zoonoz olabileceği ve özellikle enfekte hayvanların dışkı ve/veya sütleri ile kontamine olmuş süt ve süt ürünlerinin insanlar için potansiyel bir bulaşma kaynağı olabileceği ileri sürülmüştür (Ayele ve ark., 2001; Çetinkaya ve ark., 2000). Ayrıca insanlarda görülen Crohn hastalığı ile paratüberküloz arasında bir ilişki tespit edilmiştir (Nielsen 2008). Çok eskiden beri bilinen bir hastalık olmasına rağmen, patogenezi henüz tam olarak ortaya konulamamış ve dolayısıyla hastalığın kontrolü için etkili bir aşı veya uygun bir tedavi protokolü öngörülememiştir. Spesifik bir aşı veya tedavinin bulunabilmesi için Map'in, immun sistemden kaçış mekanizmalarının ve patogenezisinin anlaşılması gerekmektedir. Bu derlemede; 1) Map'in ağız yoluyla alınmasını takiben konakçıda gelişen savunma mekanizmalarına; 2) Map'in makrofajları enfekte ederek hücre içinde yaşayabilmesi ve kalıcı bir enfeksiyon oluşturabilmesi için geçen süreçte konakçı savunma mekanizmalarını nasıl önlediğgine veya değiştirdiğine yönelik bilgilere yer verildi.

\section{Map'in Vücuda Giriși}

Konakçı tarafindan sindirim yoluyla alınan Map'in, bağırsak ile ilişkili lenfoid dokuya (gutassociated lymphoid tissue, GALT) yerleştiği ve burada makrofajlar tarafindan fagosite edildiği bildirilmiștir (Lamont, 2012). Map için ilk hedefin M hücreleri olduğu ve bu hücrelerin etkenin lenfatik sisteme girişinde kapı olarak görev yaptıkları belirtilmiștir (Lamont, 2012). Oral yolla deneysel olarak enfekte edilen buzağı, keçi ve farelerde etkenin enterositler aracıllğıyla alındığı da açıklanmıştır (Bermudez ve ark., 2010). Map'in intestinal mukozaya bağlanmasında membran proteinleri ile fibronektine bağımlı bir mekanizmanın önemli rol oynadığı rapor edilmiştir (Secott ve ark., 2002; Secott ve ark., 2004). Map üzerinde bulunan fibronektin bağlayan proteinlerin, bakteriye fibronektinin bağlanmasını kolaylaştırdığı, fibronektinin intestinal epitelyal hücrelerde bulunan $\beta 1$ integrinler ile Map arasında köprü vazifesi gördüğ̈̈ ve böylece Map'in epitele bağlandığı açıklanmıștır (Pieters, 2001; Secott ve ark., 2001; Secott ve ark., 2004). Map'in özellikle M hücrelerine yerleşmesinde, enterositlerin aksine $M$ hücrelerinin luminal yüzeyinde bulunan yüksek düzeydeki $\beta 1$ integrin konsantrasyonunun neden olabileceği ileri sürülmüștür (Secott ve ark., 2001; Secott ve ark., 2004). Ayrıca, M hücrelerinde lizozomlar ile hidrolitik enzimlerin bulunmaması nedeniyle Map'in birçok antijenik 
özelliğinin değişmeden kaldığı da düşünülmektedir (Lamont, 2012). Map'in diğer epitel hücrelerinede invaze olabileceği bildirilmiş (Lamont, 2012; Secott ve ark., 2002), konakçı meme bezlerinin ise Map için rezervuar görevi görebileceği belirtilmiştir (Lamont 2012).

Epitel hücresi ile Map arasındaki ilişki yeterince araştırılmadığından, bu durumun enfeksiyonun seyrini nasıl etkilediği bilinmemektedir (Secott ve ark., 2002). Mikobakterilerde heparini bağlayan hemaglütinin (heparin-binding hemaglutinin, HBHA) ve laminini bağlayan protein (laminin binding protein, LBP) olmak üzere iki önemli adhezin tespit edilmiştir (Lefrançois ve ark., 2011; Menozzi ve ark., 1996). İlk defa Mycobacterium bovis ve Mycobacterium tuberculosis (Mtb)'de tespit edilen HBHA'nin, bakterinin hücre yüzeyinde bulunan mikobakteriyel bir adhezin olduğu bildirilmiştir (Menozzi ve ark., 1996). HBHA’nin, konağın hücre yüzeyinde bulunan, sülfatlanmış glikokonjugatlar (glikoproteinler, proteoglikanlar ve glikolipidler gibi) ile etkileşime girerek mikobakterinin epiteliyal hücrelere ve fibroblastlara bağlanmasını sağladığı ortaya konulmuştur (Menozzi ve ark., 1996; Ünübol ve Uysal, 2010). Konakçıya ve organa göre heparan sülfat gibi glikozaminoglikanların yapısında farklılıklar olduğu ve dolayısıyla mikobakteriler arasında organ protropizminin de farklı olabileceği ileri sürülmüştür (Maccarana ve ark., 1996).

\section{Map’in Enfekte Ettiği Hücrelerde Yaşaması}

\section{Map-dentritik hücre etkileşimi}

M hücresine invazyondan sonra Map'in hücre duvarı glikolipidi ve mannoz kaplı lipoarabinomannanı (ManLAM) ile bağırsak dentritik hücrelerindeki dentritik hücre reseptörü (dendritic cell receptor, DC-SIGN) aracilığıyla bağlantı kurduğu ortaya konulmuştur (Lamont, 2012). Map'in hücrelerin birbirine sıkıca bağlandığı yerden GALT’a stratejik bir manevra ile geçebilmek için bağırsak dendritik hücrelerine yerleşebileceği ve böylece Map'in hücrelerin birbirine sıkıca bağlandığı bu bariyerinden kurtulabileceği ve subepitelyal makrofajlarla iletişim için lamina propriaya direk olarak geçebileceği bildirilmiştir (Lamont, 2012).

\section{Map-makrofaj etkileşimi}

Map'in GALT’ta ilk karşılaştı̆̆ immun sistem hücrelerinden birisi makrofajlardır. İntestinal epitelyal katmanı geçtikten sonra Map'in, subepitelyal makrofajlar tarafindan fagosite edildiği açıklanmıştır (Singh ve ark., 2013). Map'in endositozunda görevli fagositik hücrelerin üzerinde Map'a ait moleküler yapıları (pathogen associated molecular patterns, PAMP) taniyan reseptörler (pattern-recognition receptors, PRR) bulunmaktadır. Map’i bağlamak için görevli önemli reseptörler (PRR) arasında komplement reseptörleri (complement receptor, CR1, CR3, CR4), mannoz reseptörü (MR), membran proteinini bağlayan bir fosfatidilinositol olan CD14 (Sohal ve ark., 2008), CD11a, CD18 gibi $\beta$-integrin reseptörleri (Mallikarjunappa 
2013), sürfaktan proteinler, mannoz bağlayan lektinler (mannose-binding lectins, MBLs), Clq, IgG ile kaplı mikobakteriler için Fcy reseptörü (Sohal ve ark., 2008), transferrin reseptörleri, toll benzeri reseptör (toll-like receptors, TLR) 2, TLR 4 (Mallikarjunappa, 2013) ve TLR 9 (Bafica ve ark., 2005; Arsenault ve ark., 2014) bulunmaktadır.

\section{Map'in hayatta kalma stratejileri}

Bakterinin makrofajlar içinde hayatta kalma stratejisini farklı mekanizmalar oluşturmaktadır. Bakterinin kullandığı bu mekanizmalar arasında; fagozom olgunlaşmasını inhibe etmesi, makrofaj apoptozisini ve fagozom asitleşmesini engellemesi (Sohal ve ark., 2008; Arsenault ve ark., 2014), büyük doku uyuşum kompleksi (major histocompatibility complex, MHC) moleküllerini azaltması (Sohal ve ark., 2008) ve sinyal iletim yollarını etkilemesi (Arsenault ve ark., 2012; Sommer ve ark., 2009) sayllabilir.

\section{Fagozom olgunlaşmast ile asitleşmesinin engellenmesi}

Fagozomun bakterisidal fagolizozoma dönüşümü, makrofajlar ve fagositik lökositlerde doğal direncin esas mekanizmasını oluşturmaktadır. Fagolizozomda zarla çevrili kapalı bir bölüm oluşturularak aktif makrofajların antimikrobial aktivitelerinin artması sağlanır ve aynı zamanda sitotoksik ürünlerin konakçıya zararı engellenir (Esen, 2005). Map' in konakçı immun sistemi tarafindan tanınmasını engellemek için makrofajların normal fagozom olgunlaşmasını değiştirdiği ve apoptozisi önleyerek makrofajların mikrobisidal etkisinden kurtulduğu ve böylece bu hücrelerin içinde uzun süre yaşayabildiği bildirilmiştir (Kuehnel ve ark., 2001; Pieters, 2001). Map'in fagozom membranını etkileyerek fagozom olgunlaşması ve fagozom-lizozom füzyonunu direk olarak engellediği açıklanmıştır (Karakousis ve ark., 2004). Mikobakteriyel lipidlerin fagozom membranı ile birleşerek membranın yapısal ve fonksiyonel özelliklerini bozduğu belirtilmiştir (Karakousis ve ark., 2004). Özellikle mikobakteriyel sülfolipidin fagozom füzyonunu bozmak için yeterli olduğu gösterilmiştir (Arsenault ve ark., 2014). Ayrıca, Map'in lipid fosfataz diğer adıyla salgısal asit fosfataz (secreted acid phosphatase, SapM) salgılayarak da fagozom membranının fonksiyonel özelliklerini etkileyebileceği bildirilmiştir (Vergne ve ark., 2005). Fagozomun gelişimi srrasında fosfatidilinositol 3-fosfat (phosphatidylinositol 3-phosphate, PI3P)'m, fagozomun lizozomal bileşikleri kazanması için mutlaka bulunması gereken bir lipid olduğu ileri sürülmüştür (Vergne ve ark., 2005). Konakçı hücreleri ölü mikobakteri $(M t b)$ ile enfekte olduğunda PI3P fonksiyonları normal iken, canlı mikobakteri ile enfekte olduğunda sürekli olarak salgılanan SapM'nin hidrolitik aktivitesi ile PI3P'ın ortadan kaldırıldığı açiklanmıştır (Brumell ve Scidmore, 2007). Map'in genomunda Mtb'de bulunan SapM ile benzer aminoasit sekansına sahip bir fosfoesteraz protein geninin varlığı bildirilmiş ve Map'in de büyük olasılıkla bu mekanizmayı kullandığı ileri sürülmüştür (Arsenault ve ark., 2014). Benzer şekilde, fagozom-lizozom füzyonu canlı Map içeren monositlerde (\%30), ölü Map içeren monositlerden (\%94) zayıf bulunmuştur 
(Woo ve ark., 2007). J774 fare makrofaj hücrelerinde canlı Map ile oluşturulan fagozom-lizozom inhibisyonunun; fagozomların üzerinde bulunan transferrin reseptörlerinde artşla ve lizozom ile ilişkili membran proteini 1 (lysosome associated membrane protein 1, LAMP-1)'de azalma ile ilişkili olduğu belirlenmiştir (Hostetter ve ark., 2003). Serin/treonin protein kinaz G (PKnG)'nin de mikobakteriyel fagozom ile lizozom füzyonunu önleyen önemli bir mikobakteriyel virülens faktörü olduğu bildirilmiştir (Walburger ve ark., 2004).

Mtb' in hücre duvarında bulunan ManLAM ile makrofajların etkileşimi üzerine yapılan çalışmalarda (Russell ve ark., 2002; Yates ve Russell, 2005), fagozom olgunlaşmasının engellenmesi için ManLAM'ın mutlaka olması gerektiği sonucuna varılmıştır. Map'in de hücre duvarında bulunan ManLAM'in dentritik hücreler ve makrofaj reseptörleri ile etkileşime girebileceği bildirilmiştir (Pieters, 2001; Rowe ve Grant, 2006). ManLAM'in tümör nekrozis faktör-alfa (TNFa) ve interleukin-12 (IL-12) gen ekspresyonunu azalttığı ve tirozin fosfataz üretiminden sorumlu olan ve makrofajlarda immun yanitı baskılayan SHP-1 (tirozin fosfataz-1 içeren Src homolog 2 bölgesi, Src homology 2 containing tyrosine phosphatase 1) gen ekspresyonunu arttırdığı belirtilmiştir (Arsenault ve ark., 2014). Makrofajların mannoz reseptörleri ile etkileşimi sonucunda fagositoz yeteneklerinin arttığı ortaya konulmuştur (Pieters, 2001; Rowe ve Grant ,2006). Map'in bir makrofaj enzimi olan sfingozin kinazı inaktive ederek fagozom olgunlaşmasını engellediği (Sohal ve ark., 2008), fosfotidilinositol3-fosfat üretimini inhibe eden bir enzim olan lipid fosfataz salgilayarak fagositik lizozomal içeriğin erimesine neden olduğu (Sohal ve ark., 2008), kıstllı fagozom füzyonuna yol açtığ1 (Singh ve ark., 2013) ve mikobakterilerin ManLAM ile makrofajların üzerindeki mannoz reseptörleri arasındaki etkileşimi engellediği (Singh ve ark., 2013) bildirilmiştir. Tüm bu olaylara bağlı olarak immun sisteme antijen sunumunu da azalttığı ileri sürülmüsștür (Weiss ve Souza, 2008). Map'in fagolizozom membran füzyonunu engellediğine dair mekanizmaların da varlığına dikkat çekilerek, bu mekanizmalardan birisinin fagozomlardan salınan ve lizozom ile füzyona olanak tanıyan bir protein olan TACO (tryptophan aspartate-containing coat protein) üretiminin engellenmesi olabileceği ileri sürülmüştür (Arsenault ve ark., 2014).

Fagozomun asitleşmesi (asidifikasyonu), fagozomun olgunlaşması için gereklidir. Çünkü lizozomal vakuollerin içerisinde bulunan hidrolitik enzimler asidik ortamda optimum katabolik aktiviteye sahiptir (Woo ve Czuprynski, 2008). Makrofajlar tarafindan oluşturulan fagozomal asitleşme, doğal dirençte MHC molekülleri aracıllğıyla antijenin işlenmesi ve sunulmasında çok önemlidir (Kuehnel ve ark., 2001). IL-1ß’nın fagozomun asitleşmesini indüklediği ve enfekte hayvanlarda enfekte olmayanlara göre 10 dakika içinde 50 kat daha fazla üretildiği saptanmıştı (Lamont, 2012). Mtb'in fagozom asitleşmesini ve olgunlaşmasını engellemek için tirozin fosfataz proteinini (protein tyrosine phosphatase, PtpA) salgıladığı belirlenmiş ve 
mikobakteriyel fagozomlarda PtpA'nın, fagozomun asitleşmesinin engellenmesinde direk etkili olduğu, bakterinin konakçının makrofajlarında yaşaması ve patojenitesi için gerekli olan anahtar bir protein olduğu savunulmuştur (Arsenault ve ark., 2014). Fagozomun asitleşmesinin ve olgunlaşmasının engellenebilmesi için Map'in canlı olması gerektiği açıklanmıştır (Arsenault ve ark., 2014). Patojen mikobakteri içeren fagozomlarda, patojen olmayan veya ölü mikroorganizma içeren fagozomlara oranla pH'nın belirgin olarak daha yüksek olduğu bildirilmiştir (Kuehnel ve ark., 2001; Woo ve Czuprynski, 2008).

\section{Süperoksit dismutaz}

Olgun fagozomun bakterisidal aktivitesi plazma membraninda bulunan nikotinamid adenin dinükleotit fosfat (nicotinamide adenine dinucleotide phosphate, NADPH) oksidaz kompleksi tarafindan üretilen süperoksit anyonu, hidrojen peroksit ve hidroksil radikalleri gibi reaktif kimyasal moleküllerinin aracilı̆ıyla gelişmektedir (Arsenault ve ark., 2014; Woo ve Czuprynski, 2008). Bu reaktiflerin mikobakterileri öldürdüğü bilinmesine rağmen, reaktif oksijen ara ürünlerinin (reactive oxygen intermediate, ROI) hücre içi Map'a karşı ne kadar etkili olduğu konusunda bir açıklama bulunmamaktadır (Arsenault ve ark., 2014). Özellikle uyarıcı maddeler ile aktive edilen sığır monositleri süperoksit anyonlarını üretirken, Map enfeksiyonunda veya Map'a karşı interferon-gama (IFN- $\gamma$ ) ile stimüle edilmiş monositlerde ROI'in oldukça az üretildiği belirtilerek, ROI'in Map'a karşı etkili olmadığı veya üretiminin konakçı tarafindan aktive edilmediği belirtilmiştir (Arsenault ve ark., 2014). Aksine bir görüş olarak ise; Map'in süperoksit dismutaz sentezleyerek süperoksit radikallerini bağladığı ve böylece kendisi için önemli bir tehdit olabilecek ROI'i nötralize ettiği açıklanmıştır (Woo ve Czuprynski, 2008). Diğer taraftan, Map'in IFN- $\gamma$ sinyalini engelleyerek ROI yanıtını durdurabileceği de ileri sürülmüştür (Arsenault ve ark., 2012).

\section{Nitrik oksit}

Fagozomlarda diğer bir anti-mikobakteriyel molekül grubu olan reaktif nitrojen ara ürünleri (reactive nitrogen intermediates, RNIs) de üretilir (Arsenault ve ark., 2014). RNI'lerin farklı türlerde ve farklı mikobakterilere karşı konakçı savunmasındaki rolleri tartısmalıdır. IFN- $\gamma$ ile aktive edilen fare makrofajlarında nitrik oksit üretiminin, mikobakterilerin öldürülmesi ile direk ilişkili olduğu saptanmıştır (Adams ve ark., 1993; Arsenault ve ark., 2014). Ancak başka bir çalışmada; IFN- $\gamma$ ile aktive edilmiş sığır makrofajlarında nitrik oksit üretiminde artış gözlenmediği açılanmıştır (Woo ve Czuprynski, 2008). Mikobakterilerin fagozomlarda nitrik oksit sentaz birikimini engelleyerek canlılıkların devam ettirdikleri belirtilmiştir (Arsenault ve ark., 2014). Kimyasal olarak nitrik oksit üretiminin durdurulduğu fare makrofajlarında $M t b$ 'nin yaşam süresinin uzadığı açıklanmıştır (Arsenault ve ark., 2014). LAM'ın makrofajları aktive ederek azot dioksit (NO2) düzeyini ve makrofajların antimikrobiyal aktivitesini arttırdığı da bildirilmiştir (Adams ve ark., 1993). 


\section{Demir}

Birçok bakteri demirin kısttlı olduğu koşullarda dahi demir temin edebilmekte ve bu nedenle demirin virülens ile ilişkili olabileceği düşünülmektedir (Woo ve Czuprynski, 2008). Map'tan hücre dısı demiri azaltan enzim izole edilmiş, bu enzim aktivitesinin $37^{\circ} \mathrm{C}$ 'de ve 5.0 ile $10.0 \mathrm{pH}$ değerleri arasında artış gösterdiği belirlenerek mikobakterinin enfeksiyon sırasında çeşitli $\mathrm{pH}$ değerlerine adapte olabileceği açıklanmıştır (Woo ve Czuprynski, 2008). Memeli hücrelerinin bakteriler tarafindan demir alınmasını engellemek için demir ihtiyaçlarını aktif olarak kısıtladığı bildirilmiş ve makrofajların hücre içi demir miktarın azaltmalarında sitokinlerin etkili olabileceği ileri sürülmüştür (Harris ve Barletta, 2001). Aktive olan makrofajlarda transferrin reseptörünün azaldığı ve böylece hücrede demir düzeyinin düştüğü belirtilmiştir (Harris ve Barletta, 2001). Monosit ve makrofajlarm lizozomlarında üretilen ve integral bir membran proteini olan Nramp 1'in, fagozomal yüzeyden demir ve iki değerlikli katyonları aktif olarak uzaklaştırarak mikobakteriyel replikasyonu kontrol ettiği ve hücre içi bakterilerin ihtiyaç duyduğu demir miktarını azalttığı açıklanmıştır (Harris ve Barletta, 2001). Demirin olmadığı veya az bulunduğu ortamlarda mikobakteri türlerinin yağda çözünebilir siderefor mikobaktin veya suda çözünebilir siderefor ekzoselin ürettiği, Map'in mikobaktin için okzotrof olması nedeniyle sadece ekzoselin sentezleyebildiği belirtilmiş ve her iki sidereforun mikobakterilerin patojenitesi ile ilişkili olduğu ileri sürülmüştür (Harris ve Barletta, 2001). Mikobaktin sentezi hasar gördügünde, insan makrofaj hücrelerinde $M t b$ 'nin replike olamadığı rapor edilmiş ancak, sadece ekzoselinleri üreterek hücre içinde hayatta kalma mekanizması açıklanamamıştır (Harris ve Barletta, 2001). Son yıllarda mikobakterilerde tip VII sekresyon sisteminin (T7SS) varlığı tespit edilerek (Tufariello ve ark., 2016), $M t b$ ve $M$. bovis' in kromozomlarnda ESX-1'den ESX-5'e kadar isimlendirilen 5 farklı T7SS kodları saptanmış; bunlardan ESX-3'ün üreme ve demir ile çinko dengesinde rol oynayabileceği ifade edilmiştir (Tufariello ve ark., 2016).

\section{Apoptozisin engellenmesi}

Mikobakteri gibi hücre içi bakteriler ile enfekte olmuş makrofajlarda apoptozis (programlı hücre ölümü), konakçı immun sisteminin henüz aktive olmadığı sırada bakterileri ortadan kaldırmada görevli önemli bir savunma mekanizmasıdır (Mallikarjunappa, 2013). Map'in kalıcı bir enfeksiyon oluşturabilmesi, antimikrobiyal yanıt aktif hale gelmeden yeni makrofajları enfekte edebilme yeteneğine bağlıdır. Apoptotik hücrelerden Map'in serbest birakılması ya da Map ile enfekte apoptotik cisimlerin fagosite edilmesinin, etkenin yangıdan ve enfekte olmayan makrofajların aktivasyonundan korunmasında rol oynayabileceği belirtilmiştir (Arsenault ve ark., 2014). Enfekte makrofajların apoptozise uğraması sonucu bakteriyel antijenlerin immun sisteme daha etkili bir şekilde sunulabileceği ileri sürülmüștür (Kabara ve Coussens, 2012). Bu nedenle Map ve diğer mikobakterilerin immun sistemden kaçıs stratejilerinden birisinin 
makrofajların apoptozisini engellemek olabileceği, böylece mikobakterilerin hem replikasyonlarını gerçekleştirebileceği hem de immun sistem tarafindan tanınmalarının engellenebileceği savunulmuştur (Kabara ve Coussens, 2012). Jolly ve ark. (2016), spesifik antikorların Map'in sığır hücreleri üzerindeki apoptozisi engelleyen etkisini kısıstladığımı ileri sürmüş ve gelişen bu immun yanıtın paratüberküloz teşhisinde veya aşı geliştirilmesinde kullanılabileceğini ifade etmişstir.

Mikobakterilerin sitokin aktivitesini etkileyerek de apoptozisten kurtulabileceği bildirilmiştir (Arsenault ve ark., 2014; Balcewicz-Sablinska ve ark., 1998). Weiss ve Souza (2008), sığır monositlerinin Map ile enfeksiyonundan sonra NF-אB yolunun aktive olarak TNF- $\alpha$ üretiminin arttı̆̆ını ve apoptozisin oluştuğunu ortaya koymuşlardır. Diğer taraftan $M t b$ tarafindan salgılanması arttırılan IL-10'un TNF- $\alpha$ üretimi baskılaması sonucu apoptozisin engellendiği rapor edilmiştir (Arsenault ve ark., 2014; Balcewicz-Sablinska ve ark., 1998).

\section{MHC (major histocompatibility complex) molekülleri üretiminin düzenlenmesi}

Mikobakteriler, makrofajların üzerinde bulunan ve antijen sunumunda görevli MHC moleküllerinin oluşmasını engelleyerek T hücre aktivasyonunu durdurabilir. MHC moleküllerinin üretimini durduran mekanizmalar arasında; MHC gen traskripsiyonunun, endozom ile lizozom birleşmesinin ve makrofajların IFN- $\gamma$ ile aktivasyonunun engellenmesi ile anti-enflamatuar sitokinlerin MHC üretimini durdurmas1 sayılabilir (Sohal ve ark., 2008; Whittington ve ark., 2012).

\section{Sinyal iletim yollarınn düzenlenmesi}

Map'in makrofajlarla ilişki kurmasından sonra farkh hücre sinyal yollarının aktive veya inhibe olduğu ve özellikle makrofajlar tarafindan üretilen doğal sitokinlerin bu sinyal yolları üzerine etkili olduğu rapor edilmiştir (Arsenault ve ark., 2012). Bu mekanizmalar arasında; IFN- $\gamma$ reseptörlerinin azalması, transkripsiyonel koaktivatörler ile bir transkripsiyon sinyal düzenleyicisi ve aktivatörü olarak tanımlanan STAT (signal transducer and activator of transcription) arasındaki ilişkinin azalması ve JAK/STAT sinyalini engellemek için bir kinaz ailesi olarak bilinen JAK' 1 (janus family kinase) bağlayarak inaktive eden bir sitokin sinyal baskilayıcısının (suppressor of cytokine signaling, SOCS) üretilmesi sayllabilir (Arsenault ve ark., 2014). Bu mekanizmalara ilaveten, ManLAM'ın bir JAK/STAT sinyalinin inhibitörü olan tirozin fosfataz1'in aktivasyonunu da kolaylaştırdığı belirtilmiştir (Arsenault ve ark., 2014). JAK-STAT yolu aktivasyonunun IFN- $\gamma$ üretimi ve $\mathrm{CD}^{+} \mathrm{T}$ hücrelerinin uyarılması için gerekli olduğu belirtilmiştir (Mallikarjunappa, 2013). Birçok patojen mikroorganizmanın çeşitli mekanizmaları kullanarak IFN- $\gamma$ ve JAK/STAT1/2 sinyalini baskıladığı ortaya konulmuştur (Arsenault ve ark., 2014; Butchar ve ark., 2008). Map'in monositlerde MAPK-p38'i (mitogen activated protein kinase-p38) aktive ettiği ve böylece hayatta kalma olasılığını arttırdığı belirlenmiştir (Sommer ve ark., 2009; Souza ve ark., 2006). 


\section{Sonuç}

Bu makalede, Map'in mukoza bariyerlerini nasıl istila ettiği ve kalıcı bir enfeksiyon oluşturmada hangi mekanizmaları kullandığı konusundaki güncel bilgiler derlendi. Enfeksiyonla mücadelede, Map invazyonu öncesi veya makrofajların içerisinde enfeksiyonun başladığı erken dönem çok önemlidir. Bugüne kadar konakçı-etken ilişkisi ile Map'in konakçı yanıtını engelleyen stratejileri henüz tam olarak açıklanamamıştır. Map in konakçı kolonizasyonunda kullandığı spesifik bileşenler veya stratejilerin herhangi birine veya kombinasyonlarına karşı yapılacak bir müdahale, tedavi veya aşı üretiminde kritik bir hedef olabilir. Bu nedenle gelecekte yapılacak araştırmalar, konakçı bağışıklık hücrelerinin Map ile enfekte olması srasında gelişen immünolojik olayları ve Map'in hayatta kalmak için geliştirdiği mekanizmaları ortaya koymaya odaklanmalidır.

\section{Kaynaklar}

1. Adams LB, Fukutomi Y, Krahenbuhl JL. 1993. Regulation of murine macrophage effector functions by lipoarabinomannan from mycobacterial strains with different degrees of virulence. Infect. Immun. 61: 41734181.

2. Arsenault RJ, Li Y, Bell K, Doig K, Potter A, Griebel PJ, Kusalik A, Napper S. 2012. Mycobacterium avium subsp. paratuberculosis inhibits interferon gamma induced signaling in bovine monocytes: insights into the cellular mechanisms of Johne's disease. Infect. Immun. 80: 30393048.

3. Arsenault RJ, Maattanen P, Daigle J, Potter A, Griebel P, Napper S. 2014. From mouth to macrophage: mechanisms of innate immune subversion by Mycobacterium avium subsp. paratuberculosis. Vet. Res. 45: 54.

4. Ayele WY, Machackova M, Pavlik I. 2001. The transmission and impact of paratuberculosis infection in domestic and wild ruminants. Vet Med-Czech, 46: 205224.

5. Bafica A, Scanga CA, Feng CG, Leifer C, Cheever A, Sher A 2005. TLR9 regulates Th1 responses and cooperates with TLR2 in mediating optimal resistance to Mycobacterium tuberculosis. J. Exp. Med. 202: 17151724.

6. Balcewicz-Sablinska KM, Keane J, Kornfeld H, Remold HG. 1998. Pathogenic Mycobacterium tuberculosis evades apoptosis of host macrophages by release of TNF-R2 resulting in inactivation of TNF- $\alpha$. J. Immunol. 161: 26362641.

7. Bermudez LE, Petrofsky M, Sommer S, Barletta RG. 2010. Peyer's patch-deficient mice demonstrate that Mycobacterium avium subsp. paratuberculosis translocates across the mucosal barrier via both $\mathrm{M}$ cells and enterocytes but has inefficient dissemination. Infect. Immun. 78: 35703577.

8. Brumell JH, Scidmore MA. 2007. Manupulation of rab GTPase function by intracellular bacterial pathogens. Microbiol. Mol. Biol. Rev. 71: 636-652.

9. Butchar JP, Cremer TJ, Clay CD, Gavrilin MA, Wewers MD, Marsh CB, Schlesinger LS, Tridandapani S. 2008. Microarray analysis of human monocytes infected with Francisella tularensis identifies new targets of host response subversion. PLoS One. 3: e2924.

10. Çetinkaya B, Muz A, Ertaş B, Öngör H, Sezen Y, Gülcü B. 2000. Süt ineklerinde paratüberküloz prevalansinin polimeraz zincir reaksiyonu (PZR) ile saptanması. Turk. J. Vet. Anim. Sci. 24: 371-379.

11. Esen N. 2005. Tüberkülozda mikobakteriyel persistans mekanizmaları. IV. Tüberküloz Sempozyumu Bildiri Kitabı, Malatya, s. 58-62.

12. Harris NB, Barletta RG. 2001. Mycobacterium avium subsp. paratuberculosis in Veterinary Medicine. Clin. Microbiol. Rev. 14: 489-512. 
13. Hostetter J, Steadham E, Haynes J, Bailey T, Cheville N. 2003. Phagosomal maturation and intracellular survival of Mycobacterium avium subspecies paratuberculosis in J774 cells. Comp. Immunol. Microb. and Infect. Dis. 26: 269-283.

14. Jolly A, Lompardíab S, Hajosb SE, Mundo SL. 2016. Evidence of a pro-apoptotic effect of specific antibodies in a bovine macrophage model of infection with Mycobacterium avium subsp. paratuberculosis. Vet. Immunol. Immunopathol. 169: 47-53.

15. Kabara E, Coussens PM. 2012. Infection of primary bovine macrophages with Mycobacterium avium subspecies paratuberculosis suppresses host cell apoptosis. Front. Microbiol. 3: 215.

16. Karakousis PC, Bishai WR, Dorman SE. 2004 Mycobacterium tuberculosis cell envelope lipids and the host immune response. Cell Microbiol. 6: 105-116.

17. Kuehnel MP, Goethe R, Habermann A, Mueller E, Rohde M, Griffiths G, Valentin-Weigand P. 2001. Characterization of the intracellular survival of Mycobacterium avium ssp. paratuberculosis: phagosomal $\mathrm{pH}$ and fusogenicity in $\mathrm{J774}$ macrophages compared with other mycobacteria. Cell Microbiol. 3: 551-566.

18. Lamont EA. 2012. Survival strategies of Mycobacterium avium subsp. paratuberculosis in a variety of microenvironments. $\mathrm{PhD}$ Thesis, The University of Minnesota, Minnesota, United States.

19. Lefrançois LH, Pujol C, Bodier CC, Teixeira-Gomez AP, Drobecq H, Rosso ML, Raze D, Dias AA, Hugot JP, Chacon O, Barletta RG, Locht C, Vidal Pessolani MC, Biet F. 2011. Characterization of the Mycobacterium avium subsp. paratuberculosis laminin-binding/histonelike protein $(\mathrm{Lbp} / \mathrm{Hll})$ which reacts with sera from patients with Crohn's disease. Microbes. Infect. 13: 585-594.

20. Maccarana M, Sakura Y, Tawada A, Yoshida K, Lindahl U. 1996. Domain structure of heparan sulfates from bovine organs. J. Biol. Chem. 271: 17804-17810.

21. Mallikarjunappa S. 2013. Cytokine gene expression in Holstein-Friesian and Jersey Calves infected with Mycobacterium avium subsp. paratuberculosis. Master Thesis, The University of Guelph, Ontario, Canada.

22. Menozzi FD, Rouse JH, Alavi M, Laude-Sharp M, Muller J, Bischoff R, Brennan MJ, Locht C. 1996. Identification of a heparin-binding hemagglutinin present in mycobacteria. J. Exp. Med. 184: 993-1001.

23. Nielsen SS. 2008. Transtions in diagnostic tests used for detection of Mycobacterium avium subsp. paratuberculosis infections in cattle. Vet. Microbiol. 132: 274-282.
24. Ott SL, Well SJ, Wagner BA. 1999. Herd-level economic losses associated with Johne's disease on US dairy operations. Prev. Vet. Med. 40: 179-192.

25. Pieters J. 2001. Entry and survival of pathogenic mycobacteria in macrophages. Microbes. Infect. 3: 249255.

26. Rowe MT, Grant IR. 2006. Mycobacterium avium ssp. paratuberculosis and its potential survival tactics. Lett. Appl. Microbiol. 42: 305-311.

27. Russell DG, Mwandumba HC, Rhoades EE. 2002. Mycobacterium and the coat of many lipids. J. Cell. Biol. 158: $421-426$

28. Secott TE, Lin TL, Wu CC. 2001. Fibronectin attachment protein homologue mediates fibronectin binding by Mycobacterium avium subsp. paratuberculosis. Infect. Immun. 69: 2075-2082.

29. Secott TE, Lin TL, Wu CC. 2002. Fibronectin attachment protein is necessary for efficient attachment and invasion of epithelial cells by Mycobacterium avium subsp. paratuberculosis. Infect. Immun. 70: 2670-2675.

30. Secott TE, Lin TL, Wu CC. 2004. Mycobacterium avium subsp. paratuberculosis fibronectin attachment protein facilitates M-cell targeting and invasion through a fibronectin bridge with host integrins. Infect. Immun. 72: 3724-3732.

31. Singh SV, Singh AV, Kumar A, Singh PK, Deb R, Verma AK, Kumar A, Tiwari R, Chakraborty S, Dhama K. 2013. Survival mechanisms of Mycobacterium avium subspecies paratuberculosis within host species and in the environment-A review. Nat. Sci. 5: 710-723.

32. Sohal JS, Singh SV, Tyagi P, Subhodh S, Singh PK, Singh AV, Narayanasamyc K, Sheoran N, Sandhu KS. 2008. Immunology of mycobacterial infections: with special reference to Mycobacterium avium subspecies paratuberculosis. Immunobiology. 213: 585-598.

33. Sommer S, Pudrith CB, Colvin CJ, Coussens PM. 2009. Mycobacterium avium subspecies paratuberculosis suppresses expression of $\mathrm{IL}-12 \mathrm{p} 40$ and iNOS genes induced by signalling through $\mathrm{CD} 40$ in bovine monocytederived macrophages. Vet. Immunol. Immunopathol. 128: 44-52.

34. Souza CD, Evanson OA Weiss DJ. 2006. Mitogen activated protein kinase p38 pathway is an important component of the anti-inflammatory response in Mycobacterium avium subsp. paratuberculosis-infected bovine monocytes. Microb. Pathog. 41: 59-66. 
35. Tufariello JM, Chapman JR, Kerantzas CA, Wong K-W, Vilchèze $\mathrm{C}$, Jones $\mathrm{CM}$, Cole LE, Tinaztepe $\mathrm{E}$, Thompson V, Fenyö D, Niederweis M, Ueberheide B, Philips JA, Jacobs WR Jr. 2016. Separable roles for Mycobacterium tuberculosis ESX-3 effectors in iron acquisition and virulence. Proc. Natl. Acad. Sci. USA. 113: E348-E357.

36. Ünübol Aypak A, Uysal H. 2010. Glikoproteinlerin yapıs ve fonksiyonlar. F. Ü. Sağ. Bil. Vet. Derg. 24: 107-114.

37. Vergne I, Chua J, Lee HH, Lucas M, Belisle J, Deretic V. 2005. Mechanism of phagolysosome biogenesis block by viable Mycobacterium tuberculosis. Proc. Natl. Acad. Sci. USA. 102: 4033-4038.

38. Walburger A, Koul A, Ferrari G, Nguyen L, PrescianottoBaschong C, Huygen K, Klebl B, Thompson C, Bacher G, Pieters J. 2004. Protein kinase $G$ from pathogenic mycobacteria promotes survival within macrophages. Science. 304: 1800-1804.

39. Weiss DJ, Souza CD. 2008. Modulation of mononuclear phagocyte function by Mycobacterium avium subsp. paratuberculosis. Vet. Pathol. 45: 829-841.
40. Whittington RJ, Begg DJ, de Silva K, Plain KM, Purdie AC. 2012. Comparative immunological and microbiological aspects of paratuberculosis as a model mycobacterial infection. Vet. Immunol. Immunopathol. 148: 29-47.

41. Woo SR, Czuprynski CJ. 2008. Tactics of Mycobacterium avium subsp. paratuberculosis for intracellular survival in mononuclear phagocytes. J. Vet. Sci. 9: 1-8.

42. Woo SR, Heintz JA, Albrecht R, Barletta RG, Czuprynski CJ. 2007. Life and death in bovine monocytes: the fate of Mycobacterium avium subsp. paratuberculosis. Microb. Pathog. 43: 106-113.

43. Yardımc H. 2006. Mycobacterium infeksiyonlan. Aydın N, Paracıkoğlu J, ed. Veteriner Mikrobiyoloji, Ankara: İlke-Emek Yayınları, s. 87-107.

44. Yates RM, Russell DG. 2005. Phagosome maturation proceeds independently of stimulation of toll-like receptors 2 and 4. Immunity. 23: 409-417. 